\title{
Gastrointestinal parasites among felids inhabiting the Serra dos Órgãos National Park, Rio de Janeiro, Brazil
}

Parasitos gastrintestinais em felídeos que habitam o Parque Nacional da Serra dos Órgãos, Rio de Janeiro, Brasil

\author{
Laís Verdan Dib ${ }^{1,2 *}$; Cecília Cronemberger ${ }^{3}$; Fabiane de Aguiar Pereira ${ }^{3}$; Paula Forain Bolais ${ }^{4}$; \\ Claudia Maria Antunes Uchôa ${ }^{2}$; Otilio Machado Pereira Bastos²; Maria Regina Reis Amendoeira'; \\ Alynne da Silva Barbosa ${ }^{1,2}$
}

\author{
${ }^{1}$ Laboratório de Toxoplasmose e outras Protozooses, Instituto Oswaldo Cruz - IOC, Fundação Oswaldo Cruz - Fiocruz, \\ Rio de Janeiro, RJ, Brasil \\ ${ }^{2}$ Laboratório de Parasitologia, Departamento de Microbiologia e Parasitologia, Universidade Federal Fluminense - UFF, \\ Niterói, RJ, Brasil \\ ${ }^{3}$ Parque Nacional da Serra dos Órgãos, Instituto Chico Mendes de Conservação da Biodiversidade - ICMBio, Teresópolis, RJ, Brasil \\ ${ }^{4}$ Unité Inserm UMR 1094 Neuroépidémiologie Tropicale, Institut National de la Santé et de la Recherche Médicale - INSERM, \\ Limoges, France
}

Received August 21, 2017

Accepted February 16, 2018

\begin{abstract}
This study aimed to investigate the species of felids that inhabit the Serra dos Órgãos National Park (Parnaso) and gastrointestinal parasites at various stages of their life cycles in the feces of these animals. Between 2013 and 2015, felid feces were collected from trails in Parnaso. The sampling points were georeferenced. A total of $82 \mathrm{fecal}$ samples were processed, of which 79 were collected on the ground, two from captured felids and one from a necropsied animal. All samples underwent coproparasitological techniques. Samples collected from the environment underwent additional trichological analysis. Fur patterns corresponding to Leopardus guttulus, Leopardus pardalis, Leopardus wiedii and Puma yagouaroundi were observed in 32 of the samples collected on the soil. High frequency of potentially parasitic evolving forms (88.6\%) was observed in felid feces, particularly eggs of the family Diphyllobothriidae (68.6\%). Besides, were also detected, eggs of superfamily Ascaridoidea (42.9\%), nematode larvae (28.6\%), eggs of order Strongylida (28.6\%), Capillaria sp. (8.6\%), Trichuris sp. (8.6\%), eggs of order Spirurida (2.9\%), unsporulated coccidian oocysts (8.6\%) and Eimeria sp. (2.9\%). Felid feces presented higher frequency of polyparasitism (60\%) than monoparasitism (28.6\%).
\end{abstract}

Keywords: Free-living wild felids, trichology, helminths, protozoa.

\section{Resumo}

Este estudo teve como objetivo pesquisar as espécies de felídeos que circulam no Parque Nacional da Serra dos Órgãos (Parnaso), bem como as formas evolutivas de parasitos gastrintestinais nas fezes desses animais. Entre 2013 e 2015, fezes de felídeos foram coletadas nas trilhas do Parnaso, sendo os pontos de coleta georeferenciados. Foram coletadas 82 amostras fecais, sendo 79 do ambiente, duas de felídeos capturados e uma de um animal necropsiado. Todas as amostras foram submetidas a técnicas coproparasitológicas, sendo as coletadas do ambiente também analisadas pela tricologia. Em 32 amostras coletadas do solo foram identificados padróes de pelos de Leopardus guttulus, Leopardus pardalis, Leopardus wiedii e Puma yagouaroundi. Elevada frequência de formas evolutivas potencialmente parasitárias $(88,6 \%)$ foi evidenciada nas fezes dos felídeos, destacando os ovos da Família Diphyllobotrhiidae (68,6\%). Além destes, também foram detectados, ovos da superfamília Ascaridoidea (42,9\%), larvas de nematoides (28,6\%), ovos da ordem Strongylida (28,6\%), Capillaria sp. (8,6\%), Trichuris sp. $(8,6 \%)$, ovos da família Spirurida (2,9\%), oocistos de coccídios não esporulados $(8,6 \%)$ e Eimeria sp. (2,9\%). As fezes dos felídeos apresentaram maior frequência de poliparasitismo (60\%) que de monoparasitismo $(28,6 \%)$.

Palavras-chave: Felídeos silvestres em vida livre, tricologia, helmintos, protozoário.

\footnotetext{
*Corresponding author: Laís Verdan Dib. Departamento de Microbiologia e Parasitologia, Instituto Biomédico, Universidade Federal Fluminense - UFF, Rua Professor Hernani de Melo, 101, CEP 24210-130, Niterói, RJ, Brasil. e-mail: laisvdib@gmail.com
} 


\section{Introduction}

Brazil is inhabited by nearly $20 \%$ of all wild felid species belonging to the genera Panthera, Puma and Leopardus (MELO et al., 2016). The following species are found in different regions of this country: the jaguar Panthera onca and the cougar Puma concolor, which are large felines; and the following medium and small-sized felids: ocelot Leopardus pardalis, Geoffroy's cat Leopardus geoffroyi, margay cat Leopardus wiedii, jaguarundi Puma yagouaroundi, pampas cat Leopardus colocolo, southern little spotted cat Leopardus guttulus and northern tiger cat Leopardus tigrinus (GENARO et al., 2001, IUCN, 2017). Regarding national conservation list, these felids are currently classified as vulnerable, with the exception of P. yagouaroundi which is categorized as endangered (BRASIL, 2014).

Felids are solitary, strictly carnivorous, territorial mammals and are usually found in forest environments (CHEIDA et al., 2006; WILSON \& MITTERMEIER, 2009). These animals are at the top of the food chain and, thus, carry out an extremely important ecological function. They actively influence several ecosystems and the population balance between carnivores and herbivores. Moreover, they contribute towards secondary seed dispersion (SARASOLA, 2016).

Over the years, mammal fauna has declined steadily across the globe for various reasons. Some of these factors are: growing closeness of contact between wild predators and domesticated animals; expansion of agricultural boundaries; deforestation and establishment of pasture; pollution of the environment; pelt trafficking; and lack of prey in these animals' natural environment (WILSON \& MITTERMEIER, 2009; ARANDA et al., 2013). Another factor that may culminate in decreasing this fauna is parasitism by different etiological agents, such as parasites (HOLMES, 1996).

The impact that parasites have on communities of wild animals has demonstrated the need to identify and survey fauna, and to assess possible infecting etiological agents (BELTRÁN-SAAVEDRA et al., 2009). Feces have been considered to be ideal tools for indirectly analyzing free-living animals, because they provide much information regarding the natural environment, such as identification of the species inhabiting that environment, diet composition, the animal's function in the ecosystem, the taxon of the ingested prey and data on the dynamics of gastrointestinal parasites (CHAME, 2003).

Gastrointestinal parasites, including protozoa and helminths, may give rise to weight loss, metabolic imbalance, reproduction disorders, anemia and dehydration among felids. In the most severe cases, these parasites can also cause fetal malformations, locomotor injuries and even death (AZPIRI et al., 2000; BARUTZKI \& SCHAPER, 2003). When parasitized, many hosts may present behavioral and functional alterations within their community. Apex predators, i.e. those at the top of the food chain, like felids, may exhibit decreased food intake and less activity, including hunting (POULIN, 1999).

The behavior of these wild felids facilitates finding their feces in the environment and consequently enables use of their feces as a tool for ecological monitoring. Since wild felids are dominant animals, they do not hide their feces. Instead, they leave them clearly visible to mark their territory (GASPARETTO, 2014).
Moreover, due to their habit of self-cleansing, felid fecal material usually contains a large amount of the animal's own hair, including the guard hairs, which are the longer spare hairs that possess bulbs. Thus, guard hairs are used for taxonomic identification of felids and other mammals, because they present morphological patterns in both the cuticle and the medullary layers, which provide determined diagnostic characteristics for a given species (QUADROS, 2002).

In investigations on gastrointestinal parasites among free-living felids, studies in which fecal material has been gathered directly from natural environments are particularly interesting, such as those conducted in parks in Thailand, in the San Miguelito Private Reserve in Bolivia and in different regions of Brazil: in the Serra da Capivara National Park, state of Piauí; Vale Natural Reserve, state of Espírito Santo, and Três Barras National Forest, state of Santa Catarina (BELTRÁN-SAAVEDRA et al., 2009; BRANDĀO et al., 2009; KUSMA et al., 2015; PATTON \& RABINOWITZ, 1994; SRBEK-ARAUJO et al., 2014).

Gastrointestinal parasites have also been reported among the results from examinations performed on the feces of felids caught in the Chaco region of Bolivia, felids held in rehabilitation centers in the states of São Paulo and Mato Grosso do Sul, Brazil, and necropsied animals in Texas and Washington, United States (FIORELLO et al., 2006; HOLSBACK et al., 2013; PENCE et al., 2003; RICKARD \& FOREYT, 1992). Nonetheless, despite the studies that have already been conducted in Brazil and other countries, there is still little information regarding gastrointestinal parasites among free-living wild animals. Given the importance of this subject for animal biodiversity conservation, the objective of the present study was to assess the frequencies of gastrointestinal parasites in fecal samples from felids, and to identify species through analyzing guard hairs present in fecal samples collected from the Serra dos Órgãos National Park, Rio de Janeiro.

\section{Materials and Methods}

\section{Ethical considerations}

This study was approved by the Animal Ethics Committee of Fiocruz, under license number LW 53/13 and protocol number P-24/13.7, and under license number 38070, authentication code 27451648, and date of issue 19/05/2013 from the Biodiversity Information and Authorization System (SISBIO).

\section{Study site}

The present study was carried out in the Serra dos Órgãos National Park (Parnaso), located in the state of Rio de Janeiro, Brazil. Parnaso is a full-protection conservation unit with a total area of 20,024 hectares, encompassing the municipalities of Teresópolis, Petrópolis, Magé and Guapimirim. The park is located within the Serra do Mar mountain range between the coordinates $22^{\circ} 23^{\prime} 37^{\prime \prime}$ and $22^{\circ} 34^{\prime} 58^{\prime \prime} \mathrm{S}$ and $43^{\circ} 10^{\prime} 58^{\prime \prime}$ and $42^{\circ} 58^{\prime} 44^{\prime \prime} \mathrm{W}$ in the Atlantic Rainforest biome.

The environment of Parnaso is extensive and rich in natural landscapes, with high biodiversity of both fauna and flora. According 
to Cronemberger \& Viveiros de Castro (2007), 735 animal species have been reported in this area, of which 462 are birds, 102 amphibians, 83 mammals, 82 reptiles and 6 fish. Among the nine species of felids that occur in Brazil, five are believed to inhabit Parnaso: P. concolor, P. yagouaroundi, L. pardalis, L. guttulus and L. wiedii (CUNHA, 2007).

\section{Fecal samples}

Between March 2013 and April 2015, a total of 82 well-formed fecal samples were obtained from Parnaso. Among these, 79 were gathered from trails during the fieldwork of park staff. In this fieldwork, collection of fecal material with morphology compatible with felid feces was prioritized. Another two samples were collected from felid that were caught and subsequently released in the park, and one was from a necropsied felid.

Fecal sample collection from the ground occurred at times when park employees in Parnaso patrolled the park trails. A total of 15 expeditions were conducted. Among these, five were conducted along the Pedra do Sino trail, which is located in the municipality of Teresópolis, from which 26 fecal samples were gathered. In Petrópolis, two expeditions were conducted along the Cobiçado Ventania trail, from which five fecal samples were collected, and one expedition along the Caxambu trail, from which one fecal sample was collected. In addition to these expeditions, another seven were conducted along the Petrópolis-Teresópolis Traverse trail, from which 47 samples were gathered.

The samples from the felids that were caught and handed over to Parnaso were gathered by removing the feces from the floor of the enclosures where these animals were temporarily kept. These animals comprised one specimen of $L$. wiedii and one of L. guttulus. In addition to these samples, feces were also collected from a specimen of $P$. yagouaroundi that was found run over on highway BR-116. This animal was necropsied at the Park's facilities.

At the time of sampling, all the fecal material was stored in plastic collectors of capacity $80 \mathrm{~mL}$ without chemical preservative, and these were identified with a number and the date of collection. The sampling points on the trails were georeferenced and analyzed using the Arc Gis ${ }^{\circledR}$ software. The fecal samples were then stored in a refrigerator at $4^{\circ} \mathrm{C}$ at the Parnaso headquarters for subsequent laboratory processing.

\section{Parasitological techniques}

The feces thus collected were forwarded to the Parasitology Laboratory of the Biomedicine Institute, Fluminense Federal University. Half of each fecal sample was weighed, homogenized in distilled water, and filtered on conical-bottom cup with a sieve with a four-time-folded gauze. The resulting filtrate was separated into three aliquots, two with $15 \mathrm{ml}$ and one with $7 \mathrm{ml}$, in conical-bottom centrifuge tubes of capacity $15 \mathrm{ml}$. For each sample was performed four quantitative coproparasitological techniques: the 7-ml aliquots were used for the modified centrifuge-sedimentation technique (RITCHIE, 1948; YOUNG et al., 1979); one of the 15-mL aliquots for the centrifuge-flotation technique (FAUST et al., 1938) using zinc sulfate at a density of $1.180 \mathrm{~g} / \mathrm{cm}^{3}$; and the other
15-mL aliquot for the modified centrifuge-flotation technique (SHEATHER, 1923; HUBER et al., 2003) with a sucrose solution of $1.300 \mathrm{~g} / \mathrm{cm}^{3}$. The remaining filtrate rested in the conical-bottom cup for 24 hours for the spontaneous sedimentation technique (LUTZ, 1919).

The microscope slides obtained from the parasitological techniques were examined and photomicrographed using an Olympus ${ }^{\circledR}$ BX 41 light microscope. Morphometry on the parasites at various stages of their life cycles was performed using a micrometric eyepiece at a magnification of $400 \mathrm{X}$.

\section{Trichological analysis}

To retrieve hairs that were present in the fecal material collected from the environment, half of the fecal samples was washed, dried and stored in plastic bags. After separating the guard hairs from the samples, these hairs were subjected to cuticle impression and medullary diaphanization techniques, following the protocol established by Quadros (2002). The cuticle and medullary impressions of the guard hairs that were retrieved from the samples were examined and photomicrographed using an Olympus ${ }^{\circledR}$ BX 41 light microscope. The guard hair patterns described by Miranda et al. (2014) and Vanstreels et al. (2010) were used to identify the species of felids.

\section{Data analysis}

Fecal samples were considered positive when at least one stage of the life cycle of a parasite (egg, larva, cyst or oocyst) was detected. The frequency of detection was obtained by dividing the number of positive samples by the total number of samples collected, with emphasis on the samples from which felids were identified through trichological analysis. The data were presented descriptively. The lowest taxonomic level possible for each parasite was identified using the morphometric patterns of the various stages of the life cycles of the parasites.

\section{Results}

A total of 82 fecal samples from free-living wild animals that inhabit Parnaso were analyzed. Among these, 79 samples (96.3\%) were collected on the ground and were subjected to taxonomic identification by means of analysis of the guard hairs present in the fecal material. The cuticle and medullary patterns of the guard hairs seen under the light microscope enabled identification of felid species from 32 samples, of which 10 (31.3\%) were compatible with L. guttulus, 5 (15.6\%) with L. pardalis, 10 (31.2\%) with L. wiedii and 7 (21.9\%) with P. yagouaroundi (Figure 2). The collection sites for these 32 fecal samples were plotted in the map of Parnaso, as shown in Figure 1.

Regarding the general frequency of helminths and protozoa, out of the 82 fecal samples analyzed, 71 (86.6\%) were positive for potentially parasites at various stages of their life cycles. Wild felid species were identified through trichological analysis, from 31 of these positive fecal samples collected on the ground. Helminths 


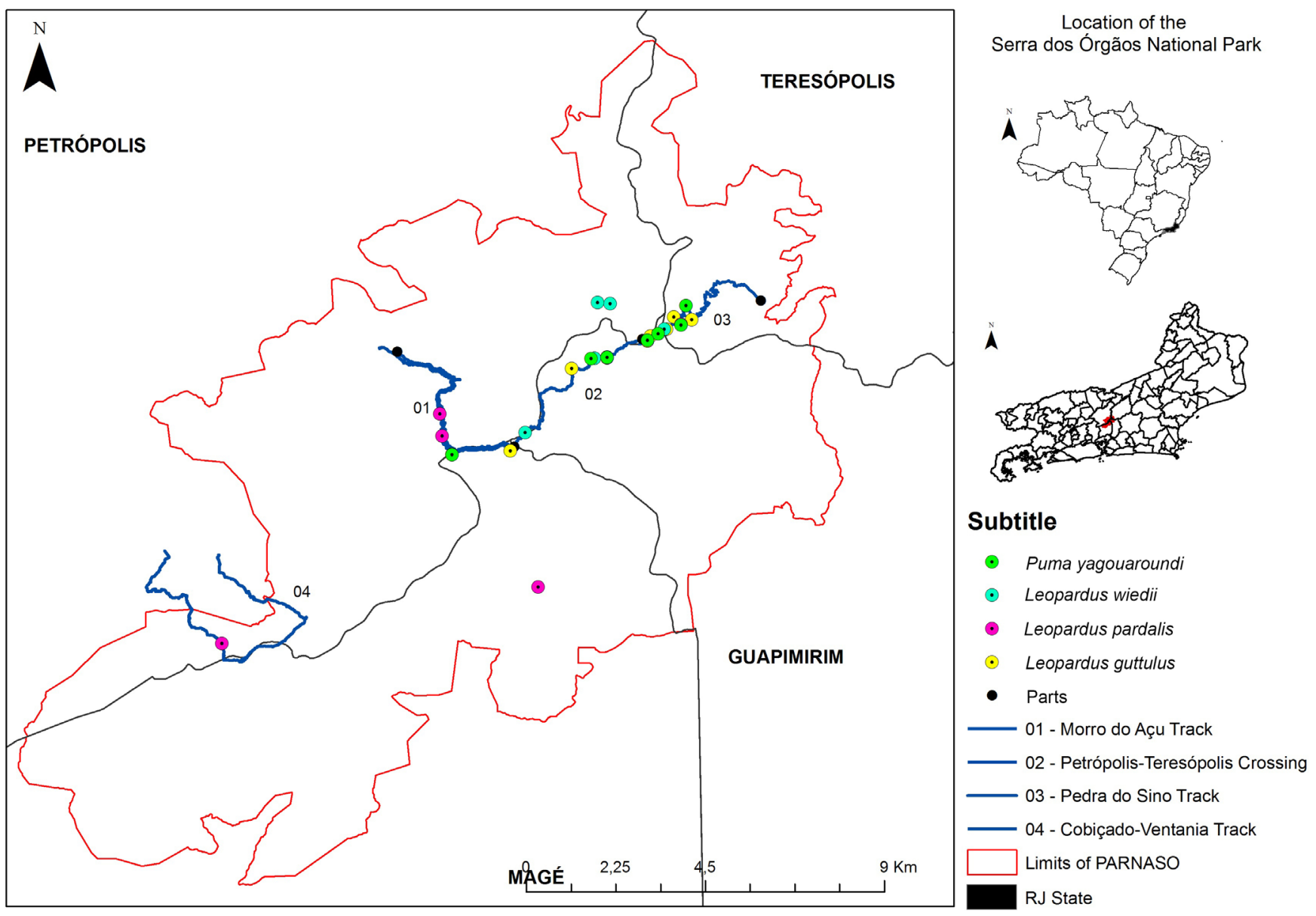

Figure 1. Location map of the Serra dos Órgãos National Park, highlighting the trails included and the collection points for the fecal samples collected on the ground, from wild felids that were identified through trichological analysis.

were more abundant than protozoa. All samples that were positive for potentially gastrointestinal parasites showed helminths at various stages of their life cycles (Table 1 ).

Considering helminths, parasites in the classes Cestoda, Nematoda and Trematoda were observed in the fecal samples examined. The most common helminth stages were cestode eggs belonging to the family Diphyllobothriidae, which occurred in 54 samples (65.8\%), and these parasites were seen 24 (68.6\%) of the fecal samples from wild felids that were identified. Eggs of superfamily Ascaridoidea was the second most frequent parasite, detected in 36 (43.9\%) of the fecal samples, of which 15 (42.9\%) were from an identified felid species. The third most frequently detected helminth was nematode larvae, followed by eggs of order Strongylida. Other helminths such as Capillaria sp., Trichuris sp., eggs of order Spirurida, and Platynosomum sp. were also identified.

Regarding protozoa, some samples were positive for the class Sporozoea. Unsporulated coccidian oocysts were identified in $3(8.6 \%)$ of the fecal samples from felids. Sporulated oocysts of Eimeria sp. were also detected in $1(2.9 \%)$ of the felid fecal samples (Table 2).

The most frequent potentially parasitic forms among all the species of felids identified were those of the family Diphyllobothriidae,
Table 1. General frequencies of the various stages of the life cycles of helminths and protozoa detected in the fecal samples that were collected from animals that inhabit Parnaso, RJ, Brazil.

\begin{tabular}{cccc}
\hline $\begin{array}{c}\text { Positivity for } \\
\text { parasites }\end{array}$ & $\begin{array}{c}\text { Fecal samples } \\
\text { from which } \\
\text { felid species } \\
\text { were identified } \\
(\mathbf{n}=\mathbf{3 5})\end{array}$ & $\begin{array}{c}\text { Fecal samples } \\
\text { from which } \\
\text { felid hair was } \\
\text { not identified } \\
(\mathbf{n}=\mathbf{4 7})\end{array}$ & $\begin{array}{c}\text { Total number } \\
\text { of samples } \\
\text { gathered } \\
(\mathbf{n}=\mathbf{8 2})\end{array}$ \\
\hline Helminths & $31(88.6 \%)$ & $40(85.1 \%)$ & $71(86.6 \%)$ \\
Protozoa & $4(11.4 \%)$ & $4(8.5 \%)$ & $8(9.7 \%)$ \\
Total positive & $31(88.6 \%)$ & $40(85.1 \%)$ & $71(86.6 \%)$ \\
\hline
\end{tabular}

seen in 7 fecal samples (63.6\%) from L. guttulus, $3(60 \%)$ from L. pardalis, $8(72.7 \%)$ from L. wiedii and 6 (75\%) from P. yagouaroundi (Table 3 ).

Polyparasitism, i.e. presence of different potentially parasitic taxa in the same sample, was observed more frequently than monoparasitism, both among the samples that presented felid guard hairs and among the samples from which no animal hairs were retrieved (Table 4). The most frequent type of polyparasitism, 

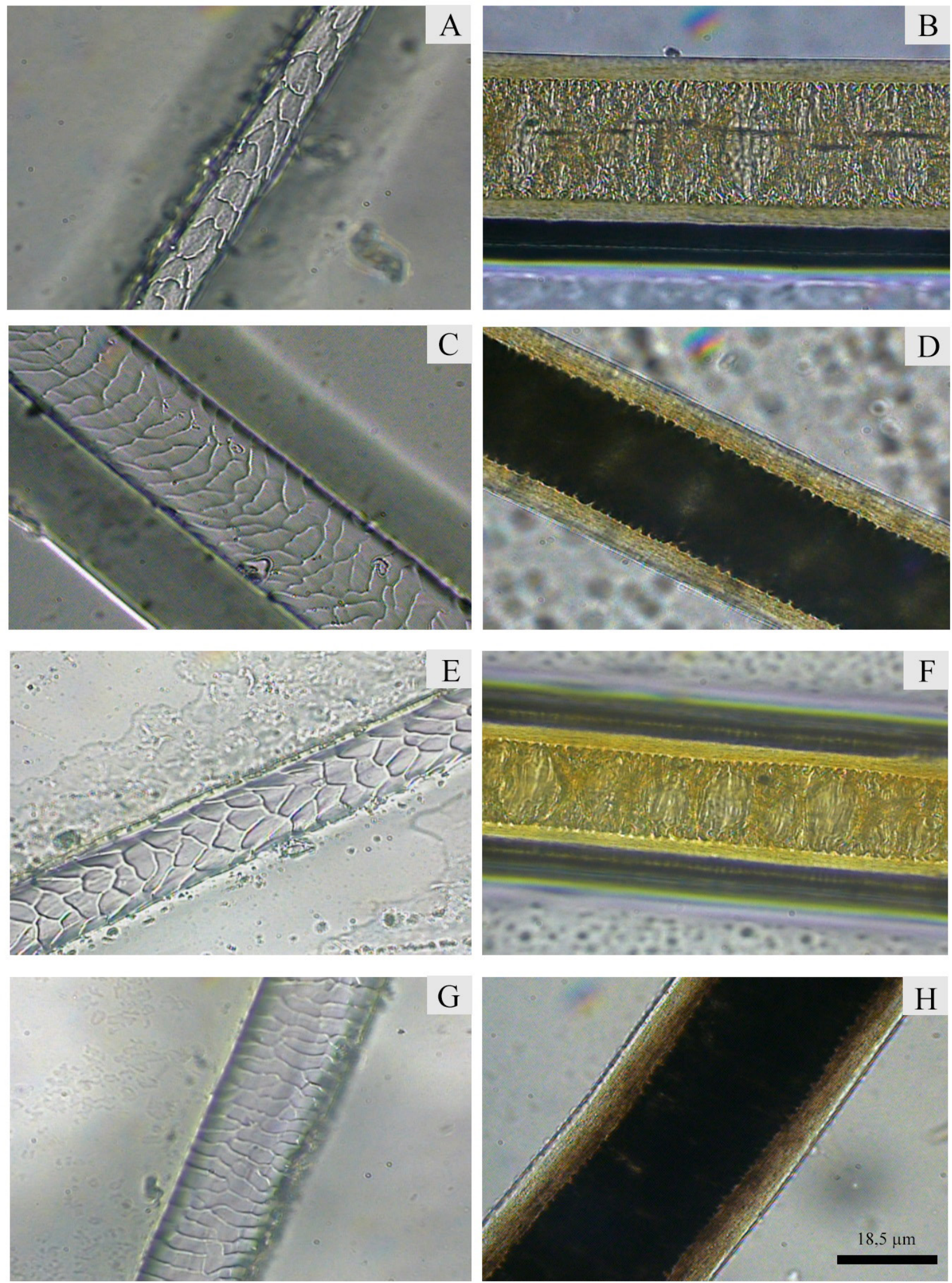

Figure 2. Cuticle and medullary patterns of the guard hairs of felids that were identified. (A) Cuticle pattern of L. guttulus - narrow non-imbricated diamond-shaped; (C) Cuticle pattern of $L$. pardalis - intermediate imbricated petal-like; (E) Cuticle pattern of $L$. wiedii - very narrow imbricated petal-like; (G) Cuticle pattern of P. yagouaroundi - non-imbricated broad diamond-shaped or slightly ornamented mosaic. (B, D, F, H) Medullary pattern of L. guttulus - trabecular and fimbriated, with medullary width greater than $2 / 3$ of hair width. The scale bar above is corresponding to the figures $(\mathrm{A}-\mathrm{H})$. 
Table 2. Frequency distribution of the stages of the life cycles of helminths and protozoa detected in the fecal samples that were collected from animals that inhabit Parnaso, RJ, Brazil.

\begin{tabular}{|c|c|c|c|}
\hline $\begin{array}{l}\text { Life stages of helminths } \\
\text { and protozoa }\end{array}$ & $\begin{array}{l}\text { Fecal samples from which felid } \\
\text { species were identified }(n=35)\end{array}$ & $\begin{array}{l}\text { Fecal samples from which felid } \\
\text { hair was not identified }(n=47)\end{array}$ & $\begin{array}{l}\text { Total number of samples } \\
\text { gathered }(\mathrm{n}=\mathbf{8 2})\end{array}$ \\
\hline \multicolumn{4}{|l|}{ Class Cestoda } \\
\hline Family Diphyllobothriidae & $24(68.6 \%)$ & $30(63.8 \%)$ & $54(65.8 \%)$ \\
\hline \multicolumn{4}{|l|}{ Class Nematoda } \\
\hline Superfamily Ascaridoidea & $15(42.9 \%)$ & $21(44.7 \%)$ & $36(43.9 \%)$ \\
\hline Nematode larvae & $10(28.6 \%)$ & $15(31.9 \%)$ & $25(30.5 \%)$ \\
\hline Order Strongylida & $10(28.6 \%)$ & $8(17 \%)$ & $18(21.9 \%)$ \\
\hline Capillaria sp. & $3(8.6 \%)$ & $3(6.4 \%)$ & $6(7.3 \%)$ \\
\hline Trichuris sp. & $3(8.6 \%)$ & $2(4.3 \%)$ & $5(6.1 \%)$ \\
\hline Order Spirurida & $1(2.9 \%)$ & $3(6.4 \%)$ & $4(4.9 \%)$ \\
\hline \multicolumn{4}{|l|}{ Class Trematoda } \\
\hline Platynosomum sp. & 0 & $2(4.3 \%)$ & $2(2.4 \%)$ \\
\hline \multicolumn{4}{|l|}{ Class Sporozoea } \\
\hline Unsporulated coccidian & $3(8.6 \%)$ & $5(10.6 \%)$ & $8(9.8 \%)$ \\
\hline \multicolumn{4}{|l|}{ Sporulated coccidian } \\
\hline Eimeria sp. & $1(2.9 \%)$ & 0 & $1(1.2 \%)$ \\
\hline Total positive & $31(88.6 \%)$ & $40(85.1 \%)$ & $71(86.5 \%)$ \\
\hline
\end{tabular}

Table 3. Frequency distribution of the stages of the life cycles of helminths and protozoa detected in the fecal samples that were collected from felines that inhabit Parnaso, RJ, Brazil.

\begin{tabular}{|c|c|c|c|c|}
\hline $\begin{array}{c}\text { Stages of life cycles of } \\
\text { helminths and protozoa }\end{array}$ & $\begin{array}{c}\text { Leopardus guttulus } \\
(\mathrm{n}=11)\end{array}$ & $\begin{array}{c}\text { Leopardus pardalis } \\
(\mathrm{n}=5)\end{array}$ & $\begin{array}{l}\text { Leopardus wiedii } \\
\quad(\mathrm{n}=11)\end{array}$ & $\begin{array}{c}\text { Puma yagouaroundi } \\
(\mathrm{n}=\mathbf{8})\end{array}$ \\
\hline \multicolumn{5}{|l|}{ Class Cestoda } \\
\hline Family Diphyllobothriidae & $7(63.63 \%)$ & $3(60 \%)$ & $8(72.72 \%)$ & $6(75 \%)$ \\
\hline \multicolumn{5}{|l|}{ Class Nematoda } \\
\hline Superfamily Ascaridoidea & $4(36.36 \%)$ & $2(40 \%)$ & $6(54.54 \%)$ & $3(37.5 \%)$ \\
\hline Nematoda larvae & $3(27.27 \%)$ & $2(40 \%)$ & $3(27.27 \%)$ & $2(25 \%)$ \\
\hline Order Strongylida & $3(27.27 \%)$ & $2(40 \%)$ & $4(36.36 \%)$ & $1(12.5 \%)$ \\
\hline Capillaria sp. & $1(9.09 \%)$ & $1(20 \%)$ & $1(9.09 \%)$ & 0 \\
\hline Trichuris sp. & 0 & 0 & $1(9.09 \%)$ & $2(25 \%)$ \\
\hline Order Spirurida & 0 & 0 & 0 & $1(12.5 \%)$ \\
\hline \multicolumn{5}{|l|}{ Class Trematoda } \\
\hline Platynosomum sp. & 0 & 0 & 0 & 0 \\
\hline \multicolumn{5}{|l|}{ Class Sporozoea } \\
\hline Unsporulated coccidian & $1(9.09 \%)$ & $1(20 \%)$ & 0 & $1(12.5 \%)$ \\
\hline \multicolumn{5}{|l|}{ Sporulated coccidian } \\
\hline Eimeria sp. & $1(9.09 \%)$ & 0 & 0 & 0 \\
\hline Total positive & $9(81.81 \%)$ & $5(100 \%)$ & $10(90.90 \%)$ & $7(87.5 \%)$ \\
\hline
\end{tabular}

Table 4. Frequencies of monoparasitism and polyparasitism observed in fecal samples collected in Parnaso, RJ, Brazil.

\begin{tabular}{cccc}
\hline $\begin{array}{c}\text { Presence of different } \\
\text { potentially parasitic taxa }\end{array}$ & $\begin{array}{c}\text { Fecal samples from which felid } \\
\text { species identified }(\mathbf{n}=\mathbf{3 5})\end{array}$ & $\begin{array}{c}\text { Fecal samples from which no felid } \\
\text { hairs were identified }(\mathbf{n}=\mathbf{4 7})\end{array}$ & Total (n= 82) \\
\hline Monoparasitism & $10(28.6 \%)$ & $12(25.5 \%)$ & $22(26.82 \%)$ \\
Polyparasitism & $21(60 \%)$ & $28(59.6 \%)$ & $49(59.8 \%)$ \\
Polyparasitism - 2 parasites & $9(25.7 \%)$ & $14(29.8 \%)$ & $23(28 \%)$ \\
Polyparasitism - 3 parasites & $7(20 \%)$ & $7(14.9 \%)$ & $14(17.1 \%)$ \\
Polyparasitism - 4 parasites & $3(8.6 \%)$ & $5(10.6 \%)$ & $8(9.8 \%)$ \\
Polyparasitism - 5 parasites & $2(5.7 \%)$ & $2(4.3 \%)$ & $4(4.9 \%)$ \\
\hline
\end{tabular}


regardless of the group of animals and the quantity of parasites, was between the stages of the life cycles of the family Diphyllobothriidae and eggs of superfamily Ascaridoidea. 11/82 (13.4\%). This association was observed in $2 / 11$ samples $(18.2 \%)$ that were identified as coming from L. guttulus, $2 / 11$ (18.2\%) from L. wiedii and 1/8 (12.5\%) from P. yagouaroundi.

\section{Discussion}

In gathering fecal samples from the environment, priority was given to searching for material with morphology compatible with felid feces. According to Chame (2003), the feces of these animals are compact and cylindrical, with well-defined subdivisions and one of the extremities slightly twisted, ending in a thinner portion known as the appendix. However, macroscopic analysis on fecal material is considered to be an unreliable diagnostic method that at most allows identification of the animal as either a large or a small felid species. Moreover, the fecal material of felids contains dietary components such as the remains of their prey, since these are strictly carnivorous animals, and also grass and hairs, due to their self-cleansing habits. All of these characteristics were observed in the samples analyzed, such that some feces samples presented excessive amounts of hair, as well as grass and seeds, pieces of bones, feathers, bird beaks, hedgehog spines and the claws and teeth of other animals.

The 79 samples collected on the ground underwent trichological analysis on the guard hairs for taxonomic classification of the felids from which these samples originated. Similarly to this study, Araujo (2014) also performed trichological analysis on samples from free-living wild carnivores in the state of Minas Gerais. However, that author observed that only $10.6 \%$ of the samples came from felids, and identified the species as P. concolor. Although Srbek-Araujo et al. (2014) did not report the total number of fecal samples collected from the environment, they identified 10 fecal samples from $P$. onca in expeditions to the Vale Natural Reserve, in the state of Espírito Santo, also using the guard hair analysis method. In turn, Kusma et al. (2015) used trichological analysis and identified $100 \%$ of the fecal samples that they also gathered in Espírito Santo, as belonging to felids. However, these authors evaluated a smaller number of samples than what was used in the present study (35 samples in their study), and only identified two felid species (L. wiedii and L. guttulus), while four species were identified in the present investigation.

No felid species could be identified through trichological analysis on 47 of the samples collected on the ground. However, in 33 of these, other animals were identified based on guard hairs. This demonstrates the possibility that the hair found in fecal samples could come from other animals, which may have been the prey of these felids, given that felids are at the top of the food chain. The fecal samples generally presented large quantities of hair. This may have made it harder to choose the hair of interest, thus possibly leading to choosing guard hairs that did not come from the felid, but from its prey instead. Nevertheless, the possibility that the fecal material came from an animal in another mammalian family and that the animal in question was not the prey, but indeed the producer of the fecal material, cannot be ruled out. For clarification, further analysis should be conducted, including use of molecular biology techniques. Among the 47 samples from which no felids were identified, trichological analysis was not possible in relation to 14 of them. Although there were always many hairs in the samples analyzed, not all samples presented guard hairs. Moreover, in some cases, the guard hairs had deteriorated, such that it was impossible to obtain either cuticle impressions or adequate staining of the medulla, thus also making a diagnosis impossible.

Identification of the felid species from which the samples case, together with the georeferenced sample collection site showed the portions of the trails where felids circulated. Rocks were found to be the preferred location for defecation, and it was commonly seen that more than one defecation had taken place at the same location. Moreover, feces from different species of felids were observed in the same areas.

Regarding the presence of stages of the life cycles of potentially gastrointestinal parasites, helminths were particularly frequent. Lower frequencies than what was observed in the present study were reported by Srbek-Araujo et al. (2014) in the Vale Natural Reserve, Espírito Santo, who found that $70 \%$ of their samples were positive for parasites. On the other hand, Patton \& Rabinowitz (1994) observed that the frequency of gastrointestinal parasites in fecal samples from felids in Thailand was $96 \%$. The richness of stages of the life cycles of parasites observed among the fecal samples in Parnaso, and among those in the previously mentioned studies, can be attributed to a variety of factors. Free-living felids circulate in natural environments that are rich in various abiotic and biotic factors, and they can become infected if they ingest contaminated water or come into contact with contaminated soil, or even if they ingest infected prey.

Eggs of family Diphyllobothriidae were generally the most common form among the stages of the life cycles of the potentially parasites observed. This family includes the genera Spirometra and Diphyllobothrium. The structures observed in the fecal samples probably belonged to the genus Spirometra, because according to Conboy (2009), the eggs of this genus present narrow extremities, which was observed in the specimens found in the present study, while eggs of the genus Diphyllobothrium tend to be more rounded. Cestodes from the order Pseudophyllidea were detected in the Vale Natural Reserve, Espírito Santo, Brazil, by Srbek-Araujo et al. (2014); eggs of Spirometra sp. were identified in fecal material from free-living felids in the Três Barras National Forest, Santa Catarina, Brazil, by Kusma et al. (2015) and in the Chaco region of Bolivia by Fiorello et al. (2006). The high frequency of cestodes seems to be directly related to the abundance of rivers and waterfalls in the park, since the biological cycle of these parasites encompasses different intermediate hosts that can inhabit this environment, such as copepods, fish, amphibians and snakes, which are commonly found animals in the Parnaso region.

Eggs of superfamily Ascaridoidea were the second most frequent form among the stages of the life cycles of the potentially parasites found in the samples analyzed. According to Rickard and Foreyt (1992), Toxocara cati has been found in the feces of several species of wild felids in various countries. In the feces analyzed in the present study, the eggs of were Toxocara-like, but incompatible in size with those reported in the literature, with mean measurements of $56.66 \mu \mathrm{m}$ in length by $47.5 \mu \mathrm{m}$ in width. Although the standard deviations were within the minimum and 
maximum measurements, these structures were mostly below the size described in the literature for the species Toxocara cati ( 85 to $90 \mu \mathrm{m}$ by $75 \mu \mathrm{m}$ ), which parasitizes felids. This could either indicate the presence of another species of genus Toxocara that has not yet been described or a parasitic adaption of the helminth to an essentially protein-rich and irregular diet, since felids need to be successful in hunting in order to feed, which is not always the case. Moreover, another ascarid with similar morphology to the eggs evidenced in this study are those of the genus Lagochilascasris. In wild felids, infection by Lagochilascaris minor was reported in a $P$. concolor necropsied in Mexico (FALCÓN-ORDAZ et al., 2016) and in subcutaneous abscesses on the face and neck from domestic cats in Uruguay (SAKAMOTO \& CABRERA, 2002). According to the authors, the eggs found measured 59-73 $\mu \mathrm{m}$ long and 45-65 $\mu \mathrm{m}$ wide.

The morphology of nematode larvae detected in the samples analyzed was not assessed. Their presence was simply observed and catalogued. Since fecal samples were collected directly from the environment, these larvae could possibly be forms of free-living nematodes. However, there is also the possibility that these larvae could be hookworms, Strongyloides sp., although infection by these helminths has only been infrequently reported (SANTOS et al., 2009), or even metastrongilids, especially those which have mollusks as intermediate hosts, such as Aelurostrongylus sp. (PATTON \& RABINOWITZ, 1994; FIORELLO et al., 2006; DI CESARE et al., 2016).

Eggs of order Strongylida were detected only in the feces that presented guard hairs. These helminths present widespread geographical distribution. Eggs of family Ancylostomatidae have been reported in felid feces in different states of Brazil, such as Espírito Santo, Piauí and Santa Catarina (BRANDÃO et al., 2009; KUSMA et al., 2015; SRBEK-ARAUJO et al., 2014). Moreover, Ancylostoma sp. and Ancylostoma tubaeforme have been detected in felid feces in Bolivia by Beltrán-Saavedra et al. (2009) and Fiorello et al. (2006), respectively. In the present study, the environment of the park seemed favorable for maintenance and transmission of these geohelminths, since a large proportion of Parnaso is composed of bare ground and has a hot and humid climate, which favors larval development and migration. Even so, the possibility of pseudoparasitism by hookworm species that parasitize other animals cannot be ruled out.

Eggs of Capillaria sp. and Trichuris sp. presented very different morphotypes within the genera, which could be an indication of occurrences of different species. Capillaria sp. eggs presented mean measurements of $66.66 \mu \mathrm{m}$ in length by $31.66 \mu \mathrm{m}$ in width and also $57.5 \mu \mathrm{m}$ in length by $27.5 \mu \mathrm{m}$ in width (WRIGHT, 1961). It should be noted that the species Calodium hepatica, formely known as Capillaria hepatica, C. plica and C. feliscati, which parasitize felids, do not release eggs in the intestinal content during their life cycle. Thus, the eggs of Capillaria sp. detected in the feces may have resulted from pseudoparasitism, or even from parasite species that have not been described yet and may inhabit the gastrointestinal tract of these animals. This could also have occurred with Trichuris sp., especially in the fecal samples in which eggs with morphology that was completely different from the species that could infect felids were observed. Nevertheless, eggs measuring $73.75 \mu \mathrm{m}$ in mean length by $36.35 \mu \mathrm{m}$ in mean width, and which presented morphometry compatible with T. campanula, a species that naturally infects felids and measures 63 to $85 \mu \mathrm{m}$ in length by 34 to $39 \mu \mathrm{m}$ in width, were also observed (HENDRIX et al., 1987).

Eggs of order Spirurida and the trematode Platynosomum sp. were detected in the material analyzed. This may have occurred because, in the life cycle of these parasites, there are various intermediate hosts (such as insects, crustaceans and mollusks), paratenic hosts (such as lacertids, amphibians and even rodents) and definitive hosts, which may be felids. Helminths of superfamily Spiruroidea and family Dicrocoeliidae were reported among free-living felids in Thailand (PATTON \& RABINOWITZ, 1994). Adults of Physaloptera rara were reported in the United States (PENCE et al., 2003) and of Physaloptera praeputialis in Santa Catarina, Brazil (QUADROS et al., 2014). In Parnaso, the animals that act as intermediate and paratenic hosts in the biological cycles of these parasites are commonly observed, which demonstrates that this environment is suitable for maintenance of the biological cycle of these parasites.

Among the protozoa, only coccidian oocysts were detected in the fecal samples analyzed. These specimens were unsporulated, with the exception of one sample from L. guttulus that contained a sporulated oocyst that matched the morphology of an oocyst of Eimeria sp. Among the samples of unsporulated coccidian oocysts, the ones in which guard hairs of L. guttulus, L. pardalis and P. yagouaroundi were identified can be highlighted. The unsporulated coccidian oocysts presented varying sizes. The largest measured $35 \mu \mathrm{m}$ in length by $35.25 \mu \mathrm{m}$ in width and were compatible with Cystoisospora felis, while those measuring $25 \mu \mathrm{m}$ by $25 \mu \mathrm{m}$ were similar to those of Cystoisospora rivolta. The smaller ones measured $15.5 \mu \mathrm{m}$ in mean length by $15 \mu \mathrm{m}$ in width, which was compatible with Toxoplasma gondii/Hammondia/Besnoitia (BARBOSA et al., 1973). In the present study, no stages of parasite life cycle compatible with cysts of either Giardia sp. or Cryptosporidium sp. were reported. Cysts of these genera have been reported in other studies, particularly in those that analyzed fecal samples from captive felids (FARRET et al., 2008) or from felids that were circulating in environments where domestic animals, especially production animals, and humans were present (OLIVEIRA et al., 2008).

Infection of felids with coccidian is directly associated with ingestion of sporulated oocysts, especially in water or through predation. This occurs in the case of coccidian belonging to the family Sarcocystidae, such as Cystoisospora sp., T. gondii, Hammondia sp. and Besnoitia sp., which form cysts containing zoites within the tissues of intermediate hosts such as mammals and birds. Duszynski et al. (2000) signaled the importance of, and the care that researchers need to take in reporting diagnoses of Eimeria sp. in felid feces, since there is still no scientific evidence of infection by these protozoa in the family Felidae. Such cases could possibly be characterized as pseudoparasitism.

Regarding the presence of different potentially parasitic taxa in a sample, polyparasitism was more common than monoparasitism in the felid fecal samples. This parasite richness among the various stages of parasite life cycles observed in the fecal material from the individuals studied here demonstrates that high frequency of co-infections was possible. Given that these were free-living felids, this result was expected, since these animals are predators and thus 
become excellent parasite bioaccumulators (ROCHA, 2013). Frequent occurrences of two or three parasite structures were reported in relation to the feces of free-living felids in a natural reserve in the state of Minas Gerais (ARAUJO, 2014). Polyparasitism has been reported in studies that analyzed small numbers of fecal samples, with results that were detailed per individual, such as in a study conducted in the San Miguelito Private Reserve in Bolivia, where associations of three to six parasite structures in the feces of $P$. onca were reported (BELTRÁN-SAAVEDRA et al., 2009). The most frequent association among the samples of the present study occurred between the most common taxa of parasites, such as the family Diphyllobothriidae and eggs of superfamily Ascaridoidea.

From analysis on the fecal material of the present study, presence of four species of neotropical felids circulating in the Parnaso region was confirmed, along with a large variety of stages of parasite life cycles in their feces. Parasitological techniques allowed identification of high frequencies of helminth eggs, especially belonging to the family Diphyllobothriidae. Despite the use of four different coproparasitological techniques for the diagnosis, this study did not aim to compare their sensitivity. This demonstrates that Parnaso presents all the elements necessary for maintenance of the biological cycles of different parasites, including those with complex biological cycles that include different types of hosts (e.g. intermediate and paratenic hosts).

The laboratory diagnoses on the fecal samples enabled indirect partial analysis on the Parnaso ecosystem. The stages of the parasite life cycles that were detected usually infect free-living wild animals such as felids, but humans may also be occasional hosts. Parasites with broad zoonotic potential that are usually detected in the feces of domestic animals and humans, such as Giardia duodenalis and Cryptosporidium sp., were not identified in the samples analyzed. The non-identification of Cryptosporidium oocysts in these feces may have occurred since no staining technique was performed for its diagnosis.

Even with the ecotourism activities practiced in this region, the Chico Mendes Institute for Biodiversity Conservation (ICMBio), which administers Parnaso, has been able to implement rules for visits and avoid circulation of other animals that do not belong to the local wild fauna. In Parnaso, these wild felids are therefore able to find an environment that is rich in natural resources, where they seem to be living in balance.

\section{Acknowledgements}

The authors thank the Serra dos Órgãos National Park, Rio de Janeiro, for its collaboration and for supplying the biological material. The authors also thank the laboratory support given by the Laboratory for Toxoplasmosis and Other Protozoan infections, Oswaldo Cruz Institute (IOC), Fiocruz, and the Parasitology Laboratory of the Fluminense Federal University.

\section{References}

Aranda R, Serrano-Martínez E, Tantaleán M, Quispe M, Casas G. Identificación y frecuencia de parásitos gastrointestinales en félidos silvestres en cautiverio en el Perú. Rev Investig Vet Peru 2013; 24(1): 360-368.
Araujo RS. Enteroparasitos de carnivoros silvestres e Canis familiaris (Linnaeus 1758) (Mammalia; Carnivora) na Reserva Particular do Patrimônio Natural Santuário do Caraça, Minas Gerais [Dissertação]. Belo Horizonte: Universidade Federal de Minas Gerais; 2014.

Azpiri GS, Maldonado FG, González GC. La importancia del estudio de enfermedades en la conservación de fauna silvestre. Vet Mex 2000; 31(3): 223-230.

Barbosa W, Fernandes WJ, Pinheiro ZB, Teixeira AA, Oliveira GSG. Coccídios encontrados em felinos (Felis catus domestica) de Goiânia. Estudo de sua biomorfologia. Rev Patol Trop 1973; 2(3): 311-319.

Barutzki D, Schaper R. Endoparasites in dogs and cats in Germany 1999-2002. Parasitol Res 2003;90(Suppl 3): S148-S150. http://dx.doi. org/10.1007/s00436-003-0922-6. PMid:12928886.

Beltrán-Saavedra LF, Angulo S, Gonzales JL. Uso de metodologías de censos muestrales indirectos de fecas para evaluar endoparásitos en mamíferos silvestres: Un ensayo en la Reserva Privada de San Miguelito, Santa Cruz, Bolivia. Ecol Boliv 2009; 44(1): 56-61.

Brandão ML, Chame M, Cordeiro JLP, Chaves SAM. Diversidade de helmintos intestinais em mamíferos silvestres e domésticos na Caatinga do Parque Nacional Serra da Capivara, Sudeste do Piauí, Brasil. Rev Bras Parasitol Vet 2009;18(Suppl 1): 19-28. http://dx.doi.org/10.4322/ rbpv.018e1004. PMid:20040186.

Brasil. Ministério do Meio Ambiente. Portaria no 444, de 17 de dezembro de 2014. Diário Oficial da República Federativa do Brasil, Brasília, DF (2014); Sec. 1:121-126, n. 245.

Chame M. Terrestrial mammal feces: a morphometric summary and description. Mem Inst Oswaldo Cruz 2003; 98(Suppl 1): 71-94. http:// dx.doi.org/10.1590/S0074-02762003000900014. PMid:12687767.

Cheida CC, Oliveira EM, Costa RF, Mendes FR, Quadros J. Ordem carnívora. In: Reis NR, Peracchi AL, Pedro WA, Lima IP. Mamíferos do Brasil. Londrina: UEL; 2006. p. 231-275.

Conboy G. Cestodes of dogs and cats in North America. Vet Clin North Am Small Anim Pract 2009; 39(6): 1075-1090, vi. http://dx.doi. org/10.1016/j.cvsm.2009.06.005. PMid:19932364.

Cronemberger C, Viveiros de Castro EB. Ciência e Conservaçáo na Serra dos Órgãos. Brasília: IBAMA, 2007.

Cunha AA. Alterações na composiçáo da comunidade e o status de conservação dos mamíferos de médio e grande porte da Serra dos Órgãos. In: Viveiros de Castro EB, Cronemberger C. Ciência e Conservação na Serra dos Órgãos. Brasília: IBAMA; 2007. p. 211-224.

Di Cesare A, Laiacona F, Iorio R, Marangi M, Menegotto A. Aelurostrongylus abstrusus in wild felids of South Africa. Parasitol Res 2016; 115(10): 37313735. http://dx.doi.org/10.1007/s00436-016-5134-y. PMid:27230016.

Duszynski DW, Couch L, Upton SJ. Coccidia (Eimeriidae) of Canidae and Felidae [online]. 2000 [cited 2016 June 17]. Available from: http:// biology.unm.edu/coccidia/carniv1.html

Falcón-Ordaz J, Iturbe-Morgado JC, Rojas-Martínez AE, García-Prieto L. Lagochilascaris minor (Nematoda: Ascarididae) from a Wild Cougar (Puma concolor) in Mexico. J Wildl Dis 2016; 52(3): 746-748. http:// dx.doi.org/10.7589/2015-09-232. PMid:27310170.

Farret MH, Fanfa VR, Silva AS, Zanette RA, Monteiro SG. Parasitismo por protozoários gastrointestinais em carnívoros silvestres mantidos em cativeiro no sul do Brasil. RPCV 2008; 103(565-566): 93-95. 
Faust EC, D’Antoni JS, Odom V, Miller MJ, Peres C, Sawitz W, et al. A critical study of clinical laboratory technics for the diagnosis of protozoan cysts and helminth eggs in feces. Am J Trop Med Hyg 1938; 1(2): 169183. http://dx.doi.org/10.4269/ajtmh.1938.s1-18.169.

Fiorello CV, Robbins RG, Maffei L, Wade SE. Parasites of free-ranging small canids and felids in the Bolivian Chaco. J Zoo Wildl Med 2006; 37(2): 130-134. http://dx.doi.org/10.1638/05-075.1. PMid:17312790.

Gasparetto C. Por que é que os gatos escondem as suas fezes? [online]. 2014 [cited 2016 June 3]. Available from: http://revistameupet.com. br/higiene-e-cuidados/porque-e-que-os-gatos-escondem-as-fezes/369/

Genaro G, Adania CH, Gomes MS. Pequenos felinos brasileiros: desconhecidos e ameaçados. Rev Cienc Hoje 2001; 170: 35-39.

Hendrix CM, Blagburn BL, Lindsay DS. Whipworms and intestinal threadworms. Vet Clin North Am Small Anim Pract 1987; 17(6): 1355-1375. http://dx.doi.org/10.1016/S0195-5616(87)50006-7. PMid:3328393.

Holmes JC. Parasites as threats to biodiversity in shrinking ecosystems. Biodivers Conserv 1996; 5(8): 975-983. http://dx.doi.org/10.1007/ BF00054415.

Holsback L, Cardoso MJL, Fagnani R, Patelli THC. Natural infection by endoparasites among free-living wild animals. Rev Bras Parasitol Vet 2013; 22(2): 302-306. http://dx.doi.org/10.1590/S1984-29612013005000018. PMid:23778826.

Huber F, Bonfim TC, Gomes RS. Comparação da eficiência da técnica de sedimentação pelo formaldeído-éter e da técnica de centrífugoflutuação modificada na detecção de cistos de Giardia sp. e oocistos de Cryptosporidium sp. em amostras fecais de bezerros. Rev Bras Parasitol Vet 2003; 12(2): 135-137.

International Union for Conservation of Nature-IUCN. The IUCN red list of threatened species [online]. Cambridge: IUCN; 2017 [cited 2017 Mar 22]. Available from: http://www.iucnredlist.org/search

Kusma SC, Wrublewski DM, Teixeira VN, Holdefer DR. Parasitos intestinais de Leopardus wiedii e Leopardus tigrinus (Felidae) da Floresta Nacional de Três Barras, SC. Luminária 2015; 17(1): 82-95.

Lutz AO. Schistosomum mansoni e a schistosomatose segundo observaçóes, feitas no Brazil. Mem Inst Oswaldo Cruz 1919; 11(1): 121-155. http:// dx.doi.org/10.1590/S0074-02761919000100006.

Melo LF, Silva DS, Vieira FC, Mello WC. Histórico e perspectiva da conservaçáo dos felinos silvestres ocorrentes no Brasil com estudos realizados entre os anos de 1945 a 2014. Rev Presença 2016; 1(4): 42-57.

Miranda GHB, Rodrigues FHG, Paglia AP. Guia de identificação de pelos de mamiferos brasileiros. Brasília: Ciências Forenses; 2014.

Oliveira CB, Soares JF, Silva AS, Silva MK, Salomão EL, Monteiro SG. Ocorrência de Giardia sp. e Cryptosporidium sp. em Leopardus weidii de vida livre. Cienc Rural 2008; 38(2): 546-547. http://dx.doi.org/10.1590/ S0103-84782008000200042.

Patton S, Rabinowitz AR. Parasites of wild felidae in Thailand: a coprological survey. J Wildl Dis 1994; 30(3): 472-475. http://dx.doi. org/10.7589/0090-3558-30.3.472. PMid:7933301.

Pence DB, Tewes ME, Laack LL. Helminths of the ocelot from Southern Texas. JWildl Dis 2003; 39(3): 683-689. http://dx.doi.org/10.7589/00903558-39.3.683. PMid:14567231.
Poulin R. The functional importance of parasites in animal communities: many roles at many levels? Int J Parasitol 1999; 29(6): 903-914. http:// dx.doi.org/10.1016/S0020-7519(99)00045-4. PMid:10480727.

Quadros J. Identificação microscópica de pêlos de mamíferos brasileiros e sua aplicação no estudo da dieta de carnivoros [Tese]. Curitiba: Universidade Federal do Paraná; 2002.

Quadros RM, Marques MST, Moura AB, Antonelli M. First report of the nematode Physaloptera praeputialis parasitizing a jaguarandi. Neotrop Bio and Conserv 2014; 9(3): 186-189.

Rickard LG, Foreyt WJ. Gastrointestinal parasites of Cougars (Felis concolor) in Washington and the first report of Ollulanus tricuspis in a sylvatic felid from North America. J Wildl Dis 1992; 28(1): 130-133. http://dx.doi.org/10.7589/0090-3558-28.1.130. PMid:1548792.

Ritchie LS. An ether sedimentation technique for routine stool examinations. Bull US Army Med Dep 1948; 8(4): 326. PMid:18911509.

Rocha FL. A rede trófica e o papel dos carnivoros silvestres (Ordem Carnivora) nos ciclos de transmissáo de Trypanosoma cruzi [Tese]. Rio de Janeiro: Fundação Oswaldo Cruz; 2013.

Sakamoto T, Cabrera PA. Subcutaneous infection of Lagochilascaris minor in domestic cats from Uruguay. Vet Parasitol 2002; 108(2): 145-152. http://dx.doi.org/10.1016/S0304-4017(02)00178-4. PMid:12208042.

Santos KR, Faciulli P, Paparotto T, Takahira RK, Lopes RS, Silva RJ. First report of Strongyloides sp. (Nematoda, Strongyloididae) in Leopardus tigrinus (Carnivora: Felidae) in the municipality of Botucatu, State of São Paulo, Brazil. Rev Bras Parasitol Vet 2009;18(Suppl 1): 77-79. http:// dx.doi.org/10.4322/rbpv.018e1016. PMid:20040198.

Sarasola JH. Big cats play a bigger role in plant preservation than we knew before [online]. 2016 [cited 2016 June 12]. Available from: http:// theconversation.com/big-cats-play-a-bigger-role-in-plant-preservationthan-we-knew-before-55043

Sheather AL. The detection of intestinal protozoa and mange parasites by a floatation technique. J Comp Pathol Ther 1923; 36: 266-275. http:// dx.doi.org/10.1016/S0368-1742(23)80052-2.

Srbek-Araujo AC, Santos JLC, Almeida VM, Guimarães MP, Chiarello AG. First record of intestinal parasites in a wild population of jaguar in the Brazilian Atlantic Forest. Rev Bras Parasitol Vet 2014; 23(3): 393 398. http://dx.doi.org/10.1590/S1984-29612014065. PMid:25271462.

Vanstreels RET, Ramalho FP, Adania CH. Microestrutura de pêlos-guarda de felídeos brasileiros: consideraçôes para a identificação de espécies. Biota Neotrop 2010; 10(1): 333-337. http://dx.doi.org/10.1590/S167606032010000100029.

Wilson DE, Mittermeier RA. The mammals of the world. Madrid: Lynx; 2009.

Wright KA. Observations on the life cycle of Capillaria hepatica (Bancroft, 1893) with a description of the adult. Can J Zool 1961; 39(2): 167-182. http://dx.doi.org/10.1139/z61-022.

Young KH, Bullock SL, Melvin DM, Spruill CL. Ethyl acetate as a substitute for diethyl ether in the formalin-ether sedimentation technique. J Clin Microbiol 1979; 10(6): 852-853. PMid:574877. 